\title{
Cross border transhumance involvement in ticks and tick-borne pathogens dissemination and first evidence of Anaplasma centrale in Burkina Faso
}

\author{
Achille S. Ouedraogo ${ }^{\mathrm{a}, \mathrm{b}, *}$, Olivier M. Zannou ${ }^{\mathrm{b}, \mathrm{c}}$, Abel S. Biguezoton ${ }^{\mathrm{b}}$, Kouassi Patrick Yao ${ }^{\mathrm{d}}$, \\ Adrien Marie Gaston Belem ${ }^{\mathrm{e}}$, Souaibou Farougou ${ }^{\mathrm{f}}$, Marinda Oosthuizen ${ }^{\mathrm{g}}$, Claude Saegerman ${ }^{\mathrm{c}}$, \\ Laetitia Lempereur ${ }^{\mathrm{h}, 1}$ \\ ${ }^{a}$ Center for Fundamental and Applied Research for Animal and Health (FARAH), Faculty of Veterinary Medicine, ULiège, 4000, Liège, Belgium \\ ${ }^{\mathrm{b}}$ Vector-borne Diseases and Biodiversity Unit (UMaVeB), International Research and Development Centre on Livestock in Sub-humid Areas (CIRDES), 454, Bobo- \\ Dioulasso 01, Burkina Faso \\ ${ }^{\mathrm{c}}$ Research Unit in Epidemiology and Risk Analysis applied to veterinary sciences (UREAR-ULg), Fundamental and Applied Research for Animal and Health (FARAH) \\ Center, Department of Infectious and Parasitic Diseases, Faculty of Veterinary Medicine, ULiège, 4000, Liège, Belgium \\ ${ }^{\mathrm{d}}$ UFR Biosciences, Université Félix Houphouët Boigny, BP V34, Abidjan 01, Côte d'Ivoire \\ e Institut du Développement Rural (IDR), Université Nazi BONI, 01 BP 1091, Bobo-Dioulasso 01, Burkina Faso \\ ${ }^{\mathrm{f}}$ Unité de Recherche sur les Maladies Transmissibles, Université d'Abomey-Calavi, BP 01 BP 2009 Cotonou, République du Bénin \\ ${ }^{g}$ Department of veterinary Tropical Diseases, Faculty Veterinary Science, University of Pretoria, 0110, Onderspoort, South Africa \\ ${ }^{\mathrm{h}}$ Laboratory of Parasitology and Parasitic Diseases, Fundamental and Applied Research for Animal and Health (FARAH) Center, Department of Infectious and Parasitic \\ Diseases, Faculty of Veterinary Medicine, ULiège, 4000, Liège, Belgium
}

\section{A R T I C L E I N F O}

\section{Keywords:}

Ticks

Tick-borne pathogens

Transhumance

Burkina Faso

BeninAnaplasma centrale

\begin{abstract}
A B S T R A C T
In West Africa, cross-border transhumance, also called seasonal migration, is known to be a very important animal production strategy, as it involves about 70 to $90 \%$ of cattle. In spite of the cattle movements, some strategic areas of transhumance remain poorly explored regarding ticks and their associated pathogens investigations. The purpose of this study is to evaluate the involvement of transhumance in the spread of cattle ticks and associated pathogens in Burkina Faso (BF) and Benin (BN), in a context of speedy invasion of West African livestock by Rhipicephalus microplus. A longitudinal survey was performed on 210 cattle from BF, monitored for ticks and tick-borne pathogens (TBP) during one seasonal transhumance. The first sampling coded "TOBF" took place in eastern BF, at the transhumance departure. A second sampling "T1BN" was carried out in northern BN, the transhumance arrival zone. A third sampling "T2BF" was done at the return of cattle in eastern BF. Ticks were morphologically identified and TBP detected with reverse line blot hybridization (RLB) assay. A total of 1027 ticks (7 species), 1006 ticks (11 species) and 1211 ticks ( 9 species) were respectively found at T0BF, T1BN and T2BF. Some species were collected at the three times of sampling without any significant difference in their relative abundances. However, other tick species appeared only at T1BN and/or T2BF. The TBP species found at the three points surveyed were Theileria annulata, Theileria mutans, Theileria velifera, Babesia bigemina and Anaplasma marginale. The most prevalent was T. mutans with 166/210 (79\%), 159/210 (75.7\%) and 78/210 $(37 \%)$ cattle positive respectively at TOBF, T1BN and T2BF. Anaplasma centrale was evidenced with $0.5 \%$ and $0.9 \%$ respectively at T0BF and T2BF. To our knowledge, this represents its first report in the study area.

Overall, the TBP prevalences were significantly lower at T2BF, highlighting the effect of tick populations changes induced by transhumance combined with the seasonal variation influence.
\end{abstract}

\footnotetext{
* Corresponding author.

E-mail addresses: achillouedraogo@gmail.com (A.S. Ouedraogo), Olivier_mahuton@yahoo.fr (O.M. Zannou), babels005@yahoo.fr (A.S. Biguezoton), ykpatrick@

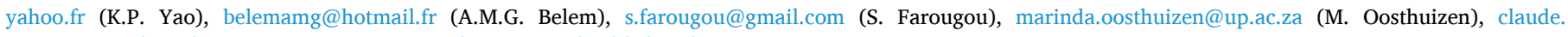
saegerman@uliege.be (C. Saegerman), Laetitia.lempereur@health.fgov.be (L. Lempereur).

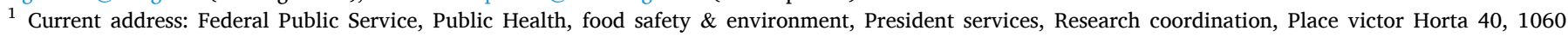
Brussels, Belgium.
} 


\section{Introduction}

In West Africa, livestock farming is characterized by seasonal movements of animals over varying distances. This is known as transhumance, defined as a system of animal production based on regular seasonal movements, occurring between complementary ecological zones. In the West African Sahel, the transhumant pastoralism is one of the most important strategy of livestock production, involving 70 to $90 \%$ of cattle (Bouslikhane, 2015). Herds migrate from pastures in the north where the rainy season is relatively short, to pastures further south where rainfall is higher and forage is more abundant (Djenontin et al., 2012; Brottem et al., 2014). These include countries such as Benin (BN), one of the wettest countries in West Africa. In the north of this country, the Atacora and Alibori departments receive a rainfall ranging from 700 to $1200 \mathrm{~mm}$ /year, which makes this region a suitable area for livestock farming and a favourite destination for Niger, Nigeria, Mali and Burkina Faso (BF) herders, seeking pasture and water points during the dry season (Lesse et al., 2015; Bouslikhane, 2015). After having walked between 150 and $200 \mathrm{~km}$, farmers of eastern BF, coming from Gourma, Kompienga and Tapoa provinces, reach northern BN (Atacora and Alibori departments) through four transhumance corridors, and three entry points identified by Zannou et al. (2020) (Fig. 1). Unfortunately, the stay of transhumant herds in northern $\mathrm{BN}$ represents a threat in recent years with regard to ticks and TBP. Indeed, for about ten years, BN has been facing an invasion of livestock by the tick $R$. microplus, accidently introduced in the south of the country in 2004 (Madder et al., 2012). Then, it spread and established from South (Mono department) to the northern departments (Borgou and Donga) only in a few years (De Clercq et al., 2012; Biguezoton et al., 2016). After molecular characterization of tick samples collected in whole of the four northern departments in 2017, a recent study evidenced its presence in Alibori and Atacora departments (Ouedraogo et al., 2021). This tick species represents a real threat as its introduction into a previously unaffected region could generate numerous issues: (i): due to its monophasic character combined with its faster life-cycle, and its high degree of acaricide-resistance, it can induce heavy burden infestation on animals (Tønnesen et al., 2004), (ii): it can induce competition with closest species (e.g. Rhipicephalus decoloratus) ending by their replacement, and the emergence of its acaricide-resistant populations, (iii): it could be at the origin of an increase of cattle babesiosis as it is known to be the efficient vector of piroplasms B. bigemina and B. bovis (Walker, 2003, Kabi et al., 2008; Adehan et al., 2016; Muhanguzi et al., 2020).

Rhipicephalus microplus is known to be introduced in the South-West of BF through transhumance movements with Ivory Coast. This results in an emergence of its acaricide resistant population in the region (Adakal et al., 2013). Meanwhile, regarding the eastern region, very limited knowledge about ticks and their associated pathogens are available, in spite of the transhumant movements with the northern Benin. This

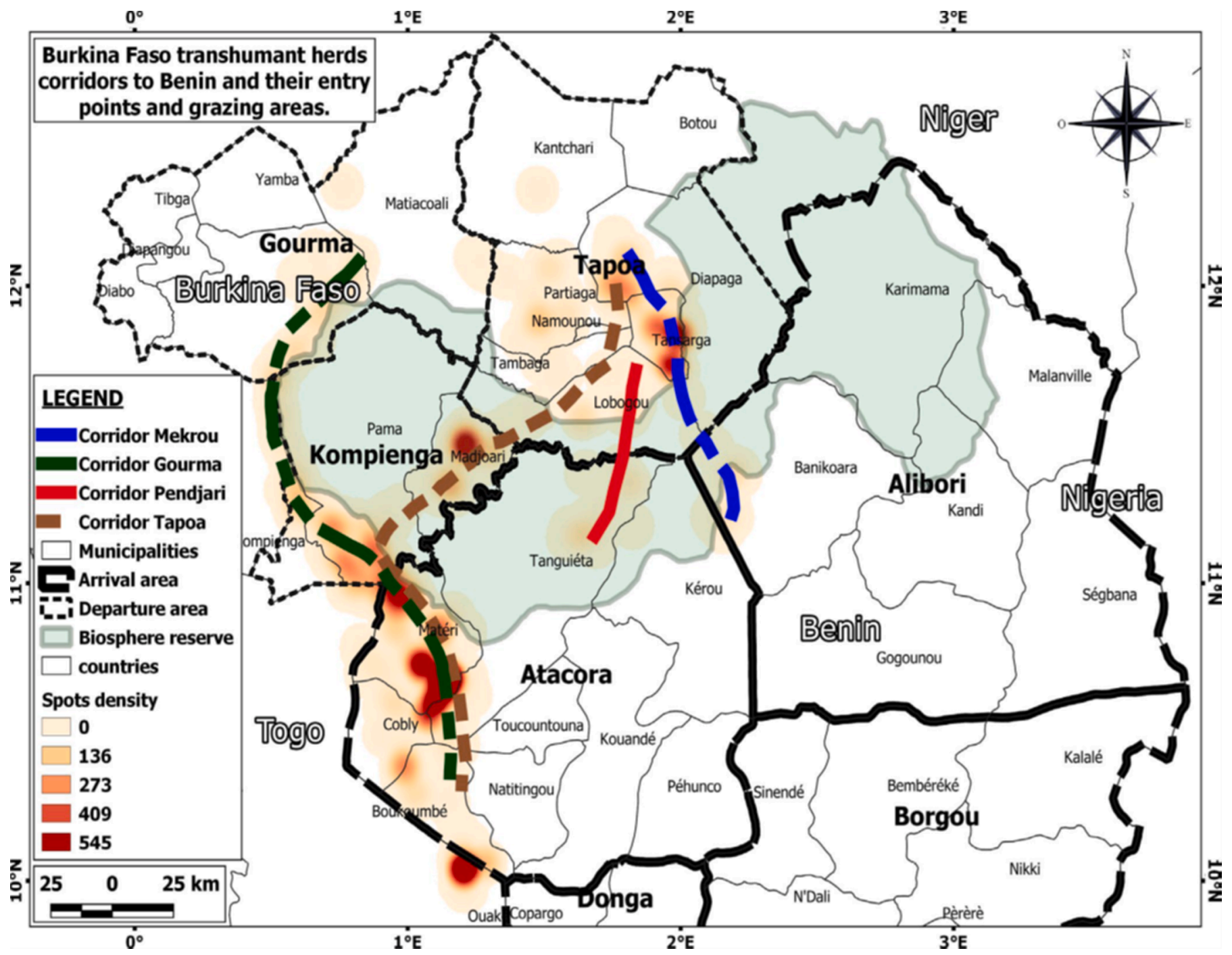

Fig. 1.. Transhumance corridors, grazing areas and entry points of Burkina Faso transhumant herds through Benin (Zannou et al., 2020). 
context of invasion, combined with the lack of data in some strategic transhumance areas, led to the implementation of this study. It aims, on the one hand, to provide updated data on areas still poorly prospected (regarding Ticks and TBP), and on the other hand, to evaluate the involvement of transhumance of cattle, in the spread of ticks and their associated pathogens in West Africa, focusing on the eastern BF and northern BN.

\section{Materials and methods}

\subsection{Study area and sampling strategy}

A longitudinal survey was carried out in eastern BF, corresponding to a transhumance departure area, and in northern BN, which represents a transhumance arrival area. Sampling was conducted in randomly selected farms with the owners' consent. A minimum distance of $2 \mathrm{~km}$ was observed between herds to avoid closeness of sampling points (at TOBF), that were recorded with the name of the locality and GPS coordinates. Cattle of both sexes, young (3-12 months-old) and adult (over 12 months-old) were involved all along the study. They were subjected to a monitoring from December 2016 to August 2017, corresponding to one seasonal transhumant duration. Sampling was carried out based on the CIRDES ethics committee for animal experimentation approval (00102/2017/CE-CIRDES) and with the owner verbal consent. Ticks and cattle blood were collected three times on the same animals. A first collect was done in eastern BF during dry season, between December 2016 and January 2017 (TOBF), selected cattle received labels as numbered earring. A second sampling was conducted in the transhumance arrival zone in northern BN from April to mid-July 2017 (T1BN) coinciding with the beginning of the rainy season. Then, a third sampling was implemented from mid-July to end of August 2017 (T2BF), in eastern BF, upon the return of cattle in their original place (Fig. 2). For tick and blood collection cattle were kept in lateral decubitus. All ticks found on visible parts were systematically removed using pliers during around $15 \mathrm{~min}$ according to Biguezoton et al. (2016). Ticks collected were stored in collection tubes with $70 \%$ alcohol. Then, approximately $5 \mathrm{ml}$ of peripheral blood per animal were collected from the tail vein or coccygeal vein in $9 \mathrm{ml}$ ethylene diamine tetra acetic acid (EDTA) treated vacutainer tubes, kept (as spots) on Whatman FTA Cards, air-dried and then packaged in safelock sealed bags with silicagel. In addition, the air temperature and humidity were continuously recorded during all sampling with heat-chips (Waranet Solutions, France). A specific questionnaire was administered to record herd information and to assess their perception of the use and efficacy of compounds employed in animal cure. They also provided data on the type of products used, sources of supply, methods, periods and frequency of treatments.

\subsection{Ticks and tick-borne pathogens identification}

Ticks were morphologically identified according to Walker et al. (2003) identification key, using standard stereomicroscope at room temperature. Tick-borne pathogens detection was performed with DNA extracted from cattle blood dried on Whatman FTA cards, and from collected tick species of veterinary interest. Ticks were grouped (per species and per cattle) and crushed in pools of a maximum five individuals in $1.5 \mathrm{ml}$ tubes. Six pieces of five $\mathrm{mm}$ diameter of dried blood Whatman FTA cards were cut and placed in $1.5 \mathrm{ml}$ tubes, and the DNeasy Blood \& Tissue Kit (Ref 69506, Qiagen; Hilden, Germany) was used according to the manufacturer's instructions. The quality and

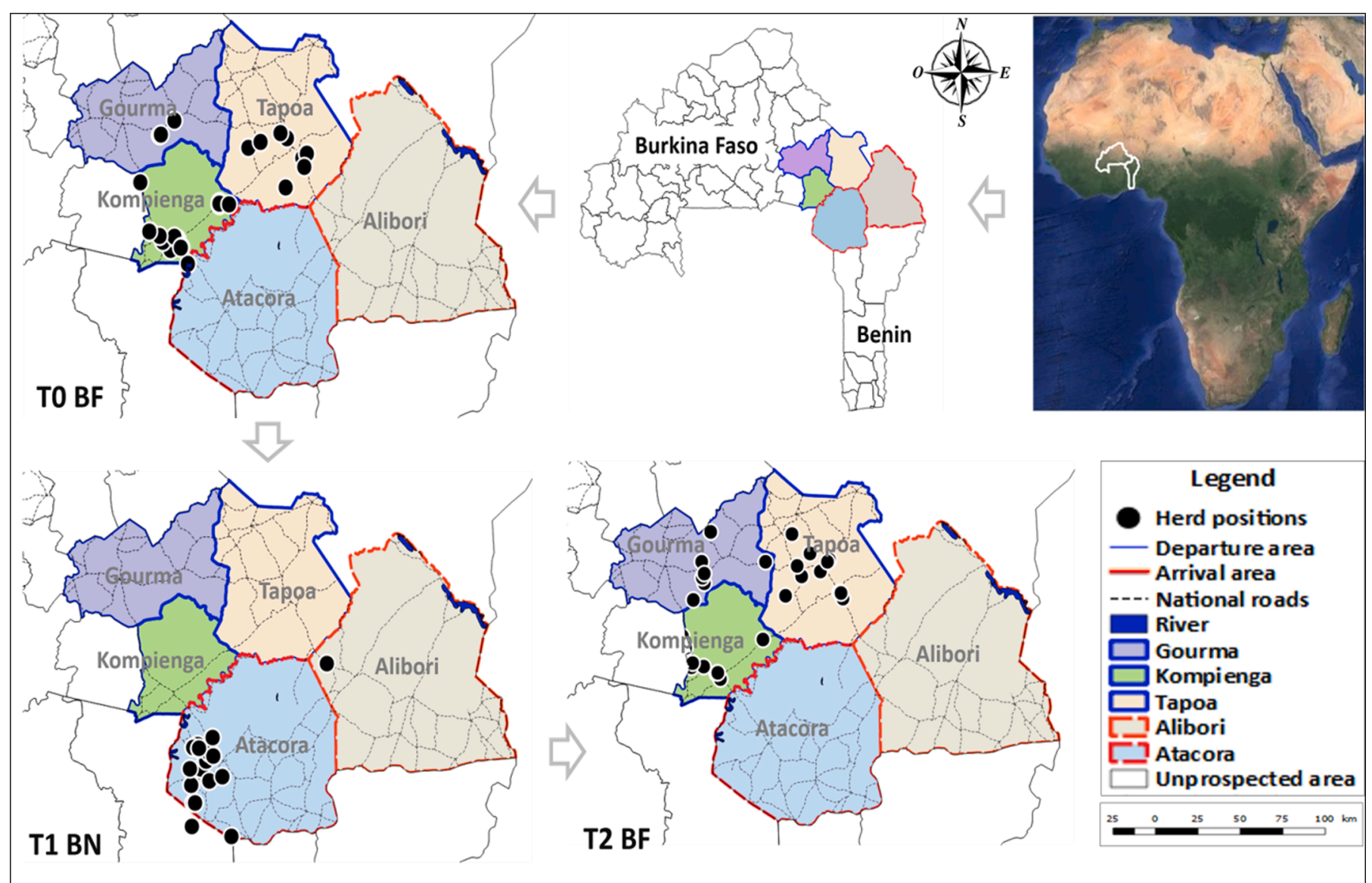

Fig. 2.. Map showing the herd positions during one seasonal transhumance: T0 in eastern Burkina Faso, T1 in northern Benin and T2 in eastern Burkina Faso. Legend: BF: Burkina Faso, BN: Benin. 
quantity of the DNA obtained was measured with Nanodrop 2000 (Thermo Fisher Scientific, USA). Each DNA sample obtained was first stored at $-20^{\circ} \mathrm{C}$, and then submitted to two generic PCR. The forward primer RLB-F2 (5'-GACACAGGGAGGTAGTGACAAG-3') and the reverse RLB-R2 (biotin-5'-CTAAGAATTTCACCTCTGACAGT-3') targeting the $18 \mathrm{~S}$ rRNA gene were used for Theileria and Babesia species detection following Nijhof et al. (2005). The forward primer Ehr-F (5'-GGAATTCAGAGTTGGATCMTGGYTCAG-3') and the reverse Ehr-R (5'-biotin-CGGGATCCCGAGTTTGCCGGGACTTYTTCT-3') targeting the 16S rRNA gene were used for Anaplasma and Ehrlichia species detection following Bekker et al. (2002). PCR protocol was optimized using a Taq PCR Master Mix Kit (Qiagen, Hilden, Germany), achieving a final volume of $16 \mu \mathrm{l}$, containing $8 \mu \mathrm{l}$ of pre-mastermix PCR buffer at $25 \mathrm{mM}$, $0.16 \mu \mathrm{l}$ of each primer at $20 \mu \mathrm{M}, 6.08 \mu \mathrm{l}$ of $\mathrm{H}_{2} \mathrm{O}$ and $20-50 \mathrm{ng}$ of template DNA. PCR products obtained were used for pathogens detection specification with RLB hybridization process (Gubbels et al., 1999; Bekker et al., 2002; Nijhof et al., 2003; Nijhof et al., 2005). Detection using RLB assay required genus and species-specific oligonucleotide probes containing an $\mathrm{N}$-terminal $\mathrm{N}$-(trifluoracetamidohexylcyanoethyl, $\mathrm{N}, \mathrm{N}$-diisopropyl phosphoramidite)-C6 listed in Table 1, binded on a nylon Biodyne-C membrane. Positive controls for each pathogen were applied to the tests, and molecular grade water was used as negative control.

\subsection{Tick-borne pathogens identification confirming}

PCR-products of some samples showing positivity for tick-borne pathogens were subsequently sequenced using Sanger method (GIGA, ULiège, Belgium) after purification (QIAquick PCR Purification Kit, Qiagen; Hilden, Germany), to confirm RLB results. Priority was given to samples showing suspicious results and then samples giving the best

Table 1.

Sequences of the used reverse line blot oligonucleotide probes.

\begin{tabular}{|c|c|c|}
\hline $\begin{array}{l}\text { Genus and species-specific } \\
\text { oligonucleotide probes }\end{array}$ & $\begin{array}{l}\text { Probe Sequences } \\
\text { (from 5'-3') }\end{array}$ & References \\
\hline $\begin{array}{l}\text { Theileria/Babesia gene- } \\
\text { specific }\end{array}$ & $\begin{array}{l}\text { TAA TGG TTA ATA } \\
\text { GGA RCR GTT G }\end{array}$ & Gubbels et al. (1999) \\
\hline $\begin{array}{l}\text { Ehrlichia/Anaplasma gene- } \\
\text { specific }\end{array}$ & $\begin{array}{l}\text { GGG GGA AAG ATT } \\
\text { TAT CGC TA }\end{array}$ & Bekker et al. (2002) \\
\hline Anaplasma marginale & $\begin{array}{l}\text { GAC CGT ATA CGC } \\
\text { AGC TTG }\end{array}$ & Bekker et al. (2002) \\
\hline Anaplasma centrale & $\begin{array}{l}\text { TCG AAC GGA CCA } \\
\text { TAC GC }\end{array}$ & Bekker et al. (2002) \\
\hline Anaplasma bovis & $\begin{array}{l}\text { GTA GCT TGC TAT } \\
\text { GRG AAC A }\end{array}$ & Bekker et al. (2002) \\
\hline Anaplasma phagocytophilum & $\begin{array}{l}\text { TTG CTA TAA AGA } \\
\text { ATA ATT AGT GG }\end{array}$ & Bekker et al. (2002) \\
\hline Ehrlichia ruminantium & $\begin{array}{l}\text { AGT ATC TGT TAG } \\
\text { TGG CAG }\end{array}$ & Bekker et al. (2002) \\
\hline Ehrlichia chaffeensis & $\begin{array}{l}\text { ACC TTT TGG TTA } \\
\text { TAA ATA ATT GTT }\end{array}$ & Schouls et al. (1999) \\
\hline Theileria annulata & $\begin{array}{l}\text { CCT CTG GGG TCT } \\
\text { GTG CA }\end{array}$ & Georges et al. (2001) \\
\hline Theileria mutans & $\begin{array}{l}\text { CTT GCG TCT CCG } \\
\text { AAT GTT }\end{array}$ & Gubbels et al. (1999) \\
\hline Theileria annae & $\begin{array}{l}\text { CCG AAC GTA ATT } \\
\text { TTA TTG ATT G }\end{array}$ & $\begin{array}{l}\text { Yisaschar-Mekuzas et al. } \\
\text { (2013) }\end{array}$ \\
\hline Theileria taurotragi & $\begin{array}{l}\text { TCT TGG CAC GTG } \\
\text { GCT TTT }\end{array}$ & Gubbels et al. (1999) \\
\hline Theileria velifera & $\begin{array}{l}\text { CCT ATT CTC CTT } \\
\text { TAC GAG T }\end{array}$ & Gubbels et al. (2000) \\
\hline Babesia occultans & $\begin{array}{l}\text { CCT CTT TTG GCC } \\
\text { CAT CTC G }\end{array}$ & He et al. (2012) \\
\hline Babesia microti & $\begin{array}{l}\text { GRC TTG GCA TCW } \\
\text { TCT GGA }\end{array}$ & Nijhof et al. (2003) \\
\hline Babesia major & $\begin{array}{l}\text { TCC GAC TTT GGT } \\
\text { TGG TGT }\end{array}$ & Georges et al. (2001) \\
\hline Babesia bovis & $\begin{array}{l}\text { CAG GTT TCG CCT } \\
\text { GTA TAA TTG AG }\end{array}$ & Gubbels et al. (1999) \\
\hline Babesia bigemina & $\begin{array}{l}\text { CGT TTT TTC CCT } \\
\text { TTT GTT GG }\end{array}$ & Gubbels et al. (1999) \\
\hline
\end{tabular}

representativity of the surveyed localities. Consensus sequences were determined with the freely available BioEdit software (http://www.mbi o.ncsu.edu/BioEdit/bioedit.htmldoads), and sequences similarities with available sequences in GenBank was evaluated via BLASTn program (https://blast.ncbi.nlm.nih.gov/Blast.cgi?PAGE_TYPE=BlastSearch). Thereafter, sequences were aligned with Clustal W method and maximum likelihood phylogenetic trees were generated in Mega_X_10.1.7 (https://www.megasoftware.net/). The percentage of bootstraps were calculated applying 500 replicates.

\subsection{Data analysis}

The relative abundances of each tick species, and the TBP prevalences recorded on the three strategic times of the seasonal transhumance were compared with the non-parametric Kruskal-Wallis test in GraphPad Prism software version 9.0.1 (San Diego, CA, USA). Cattle were grouped by two-week intervals over the sampling periods and with regard to the sampling dates. Tick species average abundances were computed in each interval, to estimate the temporal variations of the abundances of each tick species in relation to relative humidity and temperature. This was performed using the Poisson adjustment model (identity link function) in Generalized linear models (GLM). Poisson regression coefficients of temperature and humidity (explanatory variables) were compared to the null hypothesis by $\mathrm{Z}$ test. The choice of the model was based on that minimizing the Akaike Information Criterion (AIC) and the residual deviance. This was performed in Stata/SE 14.2. For all analyses, a $P$-value below 0.05 was considered for statistical significance.

\section{Results}

\subsection{Characteristics of cattle involved in the study}

A total of 311 cattle belonging to 28 farms were involved in the study at TOBF in eastern Burkina Faso. Due to some external factors, such as deaths and losses, some cattle were not found at the second and third collection times. Thus, 260 were found at T1BN, and 233 at T2BF. Only data collected on $\mathrm{N}=210$ cattle (from the 28 hers) found at the three times of sampling were involved in the analysis. A total of $81(38.6 \%)$ of them were between 3 and 12 months of age, while $129(61.4 \%)$ were over 12 months old. There were 35 (16.7\%) males and 175 (83.3\%) females. After leaving eastern BF in dry season (December-January), the herds travel between 150 and $200 \mathrm{~km}$ for about 21 days to reach northern BN. Most of them (27/28; 96\%) stay in Atacora department, where they practice free grazing, with access to crop residues and watering points. They live in this locality for about 3-4 months. The end of their stay corresponds with the beginning of the rainy season (MayJune).

\subsection{Tick species identified}

On the 210 cattle sampled all along the study, a total of 13 tick species were found with an average number of ticks per cattle of 4.9 at T0BF, 4.8 at T1BN and 5.8 at T2BF. The species Amblyomma variegatum, Hyalomma truncatum, Hyalomma rufipes, Rhipicephalus sanguineus s.l., Rhipicephalus geigyi and $R$. decoloratus were identified at all three times surveys with $A$. variegatum being the most sampled tick species (Table 2). A comparison of their relative abundance showed no significant difference $(\mathrm{p}>0.05)$ when moving from the transhumance departure area to the arrival area and vice-versa. The largest number of tick species was collected in the northern BN with the additional presence of Hyalomma impressum (0.3\%), Hyalomma nitidum (0.3\%) and Rhipicephalus annulatus (0.01\%). Rhipicephalus mushamae was sampled at TOBF and T1BN, while Rhipicephalus lunulatus was found at T1BN and T2BF. Only one individual of the invasive tick R. microplus was collected at T2BF (Table 2). 
Table 2.

Tick species collected according to transhumance departure and arrival provinces/departments.

\begin{tabular}{|c|c|c|c|c|c|c|c|c|c|c|c|}
\hline Tick species & $\begin{array}{l}\text { T0 BF } \\
\text { Gou } \\
(n=62)\end{array}$ & $\begin{array}{l}\text { Kom } \\
(n=75)\end{array}$ & $\begin{array}{l}\text { Tap } \\
(\mathrm{n}=73)\end{array}$ & $\begin{array}{l}\text { Total } \\
\text { No.(RA\%) }\end{array}$ & $\begin{array}{l}\text { T1 BN } \\
\text { Ali } \\
(\mathrm{n}=7)\end{array}$ & $\begin{array}{l}\text { Ata } \\
(n=203)\end{array}$ & $\begin{array}{l}\text { Total } \\
\text { No.(RA\%) }\end{array}$ & $\begin{array}{l}\text { T2 BF } \\
\text { Gou } \\
(n=62)\end{array}$ & $\begin{array}{l}\text { Kom } \\
(n=75)\end{array}$ & $\begin{array}{l}\text { Tap } \\
(\mathrm{n}=73)\end{array}$ & $\begin{array}{l}\text { Total } \\
\text { No.(RA\%) }\end{array}$ \\
\hline Amblyomma variegatum & 199 & 125 & 134 & $458(44.6)$ & 21 & 406 & $427(42.4)$ & 151 & 222 & 257 & $630(52.0)$ \\
\hline Hyalomma truncatum & 35 & 68 & 93 & $196(19.1)$ & 1 & 240 & $241(24)$ & 61 & 132 & 61 & $254(21)$ \\
\hline Hyalomma rufipes & 21 & 28 & 40 & $89(8.7)$ & 15 & 180 & $195(19.4)$ & 52 & 103 & 76 & $231(19.1)$ \\
\hline Hyalomma impeltatum & - & - & - & 一 & - & - & - & 2 & - & - & $2(0.2)$ \\
\hline Hyalomma impressum & - & - & - & 一 & - & 3 & $3(0.3)$ & - & - & - & - \\
\hline Hyalomma nitidum & - & - & - & 一 & - & 3 & $3(0.3)$ & - & - & - & 一 \\
\hline Rhipicephalus lunulatus & - & - & - & 一 & - & 3 & $3(0.3)$ & - & - & 5 & $5(0.4)$ \\
\hline Rhipicephalus sanguineus s.l. & 8 & 5 & 12 & $25(2.4)$ & - & 2 & $2(0.2)$ & 5 & - & - & $5(0.4)$ \\
\hline Rhipicephalus mushamae & 1 & - & 1 & $2(0.2)$ & - & 3 & $3(0.3$ & - & - & - & 一- \\
\hline Rhipicephalus geigyi & 43 & 43 & 21 & $107(10.4)$ & - & 106 & $106(10.5)$ & 7 & 69 & 1 & $77(6.4)$ \\
\hline Rhipicephalus decoloratus & 17 & 18 & 42 & $77(7.5)$ & - & 22 & $22(2.2)$ & 3 & 2 & 1 & $6(0.5)$ \\
\hline Rhipicephalus microplus & - & - & - & - & - & - & - & - & 1 & - & $1(0.01)$ \\
\hline Rhipicephalus annulatus & - & - & - & 一 & - & 1 & $1(0.01)$ & - & - & - & - \\
\hline Total & & & & $1027(100)$ & & & $1006(100)$ & & & & $1211(100)$ \\
\hline
\end{tabular}

RA: Relative Abundance; Gou: Gourma, Kom: Kompienga, Tap: Tapoa, Ata: Atacora; Ali: Alibori ; $\mathrm{n}$ : number of bovine sampled in each province, No: total number of cattle.

\subsection{Variation of tick species abundance during transhumance}

The average number of ticks per cattle was computed by two weeks intervals, extended over the sampling period. The average number of A. variegatum and $H$. rufipes increases globally from T0BF to T2BF and is significantly related to the air relative humidity (Coef: $0.01 ; \mathrm{p}<0.05$ ). The opposite phenomenon was observed with $R$. decoloratus. The average number of this species decreases from T0BF to T2BF and is inversely proportional to the relative humidity (Coef: -0.003 ; $\mathrm{p}<$ 0.0001 ). The variation of $H$. truncatum and $R$. geigyi abundances does not show any particular upward or downward trend, and does not depend on relative humidity ( $p>0.05$ ). The average temperature does not fluctuate widely over the collection period and does not show a significantly link with the variation of any tick species burden on cattle ( $\mathrm{p}>$ 0.05) (Fig. 3, Table 3).

\subsection{Evaluation of nymph and adult Amblyomma variegatum burdens of cattle}

A focus on the most abundant tick species in the study area, A. variegatum, revealed a low presence of adult ticks at TOBF. Adult abundance increases from T1BN until reaching sometimes 3 individuals per cattle at T2BF. This variation is significantly related to the relative humidity (Coef: $0.03 ; \mathrm{p}<0.0001$ ) (Table 4). In the contrary, the cattle burden in nymph $A$. variegatum infestation decreases from T0BF to T2BF, and is inversely related to relative humidity variations (Coef: $-0.01 ; \mathrm{p}<$ 0.0001) (Fig. 4, Table 4).

\subsection{Tick-borne pathogens identification in cattle blood}

The TBP species found at the three times survey were $T$. annulata, $T$. mutans, T. velifera, B. bigemina and A. marginale. The most prevalent was T. mutans with $79 \%, 75.7 \%$ and $37.1 \%$ of cattle positive respectively at T0BF, T1BN and T2BF. The species B. bovis, was found only at T0BF with

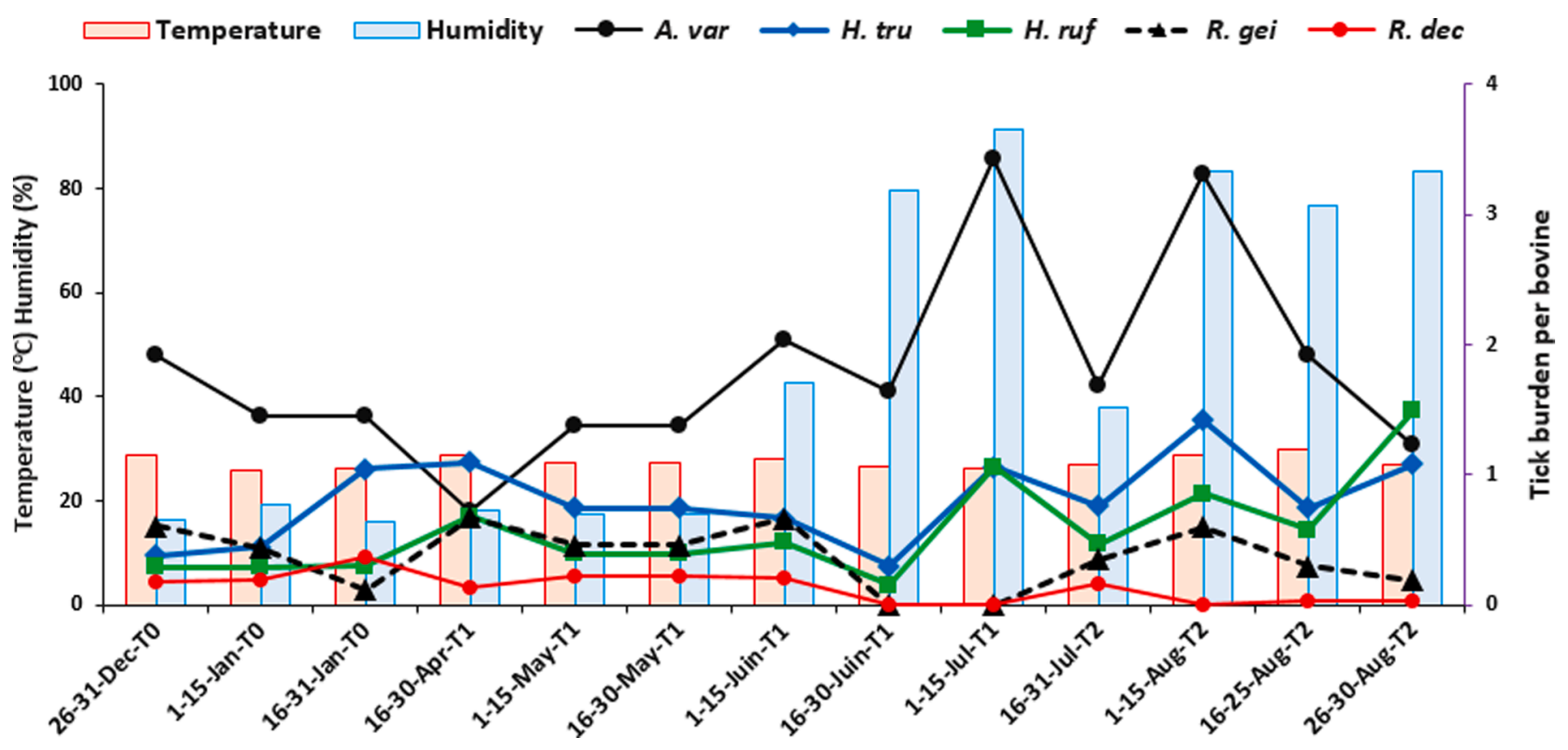

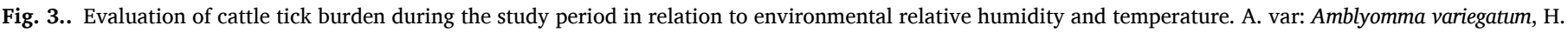
tru: Hyalomma truncatum, H. ruf: Hyalomma rufipes, R. gei: Rhipicephalus geigyi, R. dec: Rhipicephalus decoloratus. 
Table 3.

Link between relative humidity and temperature, and the variation of the average tick burden on cattle during transhumance.

\begin{tabular}{|c|c|c|c|c|c|c|c|c|c|c|c|c|c|c|c|}
\hline & \multicolumn{3}{|c|}{ A. variegatum } & \multicolumn{3}{|c|}{ H. truncatum } & \multicolumn{3}{|c|}{ H. rufipes } & \multicolumn{3}{|c|}{ R. geigyi } & \multicolumn{3}{|c|}{ R.decoloratus } \\
\hline & Coef & SE & $\mathrm{P}$ & Coef & SE & $\mathrm{P}$ & Coef & SE & $\mathrm{P}$ & Coef & SE & $\mathrm{P}$ & Coef & SE & $\mathrm{P}$ \\
\hline Temp & -0.048 & \pm 0.033 & 0.152 & 0.008 & \pm 0.026 & 0.74 & -0.003 & \pm 0.018 & 0.85 & -0.016 & \pm 0.017 & 0.35 & -0.01 & \pm 0.006 & 0.01 \\
\hline Hum & 0.012 & \pm 0.004 & 0.006 & 0.002 & \pm 0.003 & 0.47 & 0.005 & \pm 0.0025 & 0.028 & -0.002 & \pm 0.001 & 0.3 & -0.003 & \pm 0.0007 & $<0.0001$ \\
\hline
\end{tabular}

Coef : poisson regression coefficients; $\mathrm{SE}$ : standard error ; $P$ : p-value of $\mathrm{Z}$ test comparing poisson regression coefficients with null hypothesis

Table 4.

Burdens of Amblyomma variegatum stages evaluation on cattle during one seasonal transhumance in relation to relative humidity and temperature.

\begin{tabular}{lllllll}
\hline & \multicolumn{3}{c}{ Adult Amblyomma variegatum } & \multicolumn{3}{c}{ Nymph } \\
& Coef & SE & p value & Coef & SE & p value \\
\hline Temperature & 0.015 & \pm 0.014 & 0.3 & -0.06 & \pm 0.03 & 0.038 \\
Humidity & $\mathbf{0 . 0 2 5}$ & $\pm \mathbf{0 . 0 0 3}$ & $<\mathbf{0 . 0 0 0 1}$ & $\mathbf{- 0 . 0 1}$ & $\pm \mathbf{0 . 0 0 3}$ & $<\mathbf{0 . 0 0 0 1}$ \\
\hline
\end{tabular}

Coef : poisson regression coefficients; SE: standard error; $P$ : p-value of $\mathrm{Z}$ test comparing poisson regression coefficients with null hypothesis

$3.3 \%$ of cattle positive, while B. bigemina was detected at TOBF (4.8\%), T1BN (9.5\%) and T2BF (1.4\%) (Table 5). The A. centrale species was evidenced with low prevalences at TOBF and T2BF. Globally, the TBP prevalences were significantly lower $(\mathrm{p}<0.05)$ at T2BF, than at T0BF and T1BN according to Kruskal-Walis test (Fig. 5, Table 5).

\subsection{Tick-borne pathogens identification in tick pools}

Overall, ТВP prevalences were lower in tick pools than in cattle blood. A total of 347 pools were analyzed at TOBF and six TBP species were identified, 332 pools analyzed at T1BN for two TBP species identified, and 304 pools analyzed at T2BF with six TBP species found (Table 6). T. mutans was the TBP species mostly detected at the three times of sampling with $4.9 \%$ (17/347), 2.1\% (7/332) and 9.5\% (29/ 304 ) of positive pools respectively at T0BF, T1BN and T2BF. The second most prevalent tick species was $T$. velifera identified with $2.3 \%(8 / 347)$, $0.6 \%(2 / 332)$ and $4.3 \%(13 / 304)$ of positive pools respectively at T0BF, T1BN and T2BF (Table 6).

\subsection{Phylogenetic analyses}

Analysis of sequences throught BLASTn showed high identity values (i.e. 99-100) with published sequences in GenBank database, confirming TBP molecular identification with RLB hybridization assay. Furthermore, in Fig. 6A, the maximum likelihood phylogenetic tree showed a perfect clustering of $A$. centrale sequence (MW544746) generated in this survey, in clade I with other strains from South Africa (KU598854.1), Philipines (JQ839010.1), China and Iraq (MH588233.1). A similar observation is noted for Ehrlichia ruminantium sequence (MW544747), which grouped in clade III with sequences from West, East and South Africa. These two clades are clearly distinguishable from clade II, which regroup only $A$. marginale strains. In Fig. $6 \mathrm{~B}, \mathrm{~B}$. bigemina sequence (MW545174) generated in this survey clustered with that of Brazil (KC858976.1) and to a lesser extent, that of China (MG874651.1).

\section{Discussion}

In savannah regions such as $\mathrm{BF}$, the breeders practice transhumance for the search of green pastures and water points for livestock during droughts (Abdourazakou, 2016). In this study, the sampling strategy, which consisted to conduct the first survey (TOBF) at the herds' departure for transhumance, coincided with the dry season. As relative humidity and temperature have been reported as predominant factors influencing the life cycle activity and fecundity of tick populations (Yeruham et al., 1996; Yakhchali and Hosseine, 2006), this certainly led to the sampling of tick species and tick stages that tolerate low levels of relative humidity and high temperature. According to data collected, the influences of these factors were mainly apparent in the case of

\section{Temperature $\square$ Humidity $\longrightarrow$ Adult A. variegatum $\quad--\downarrow-\cdot N y m p h$ A. variegatum}

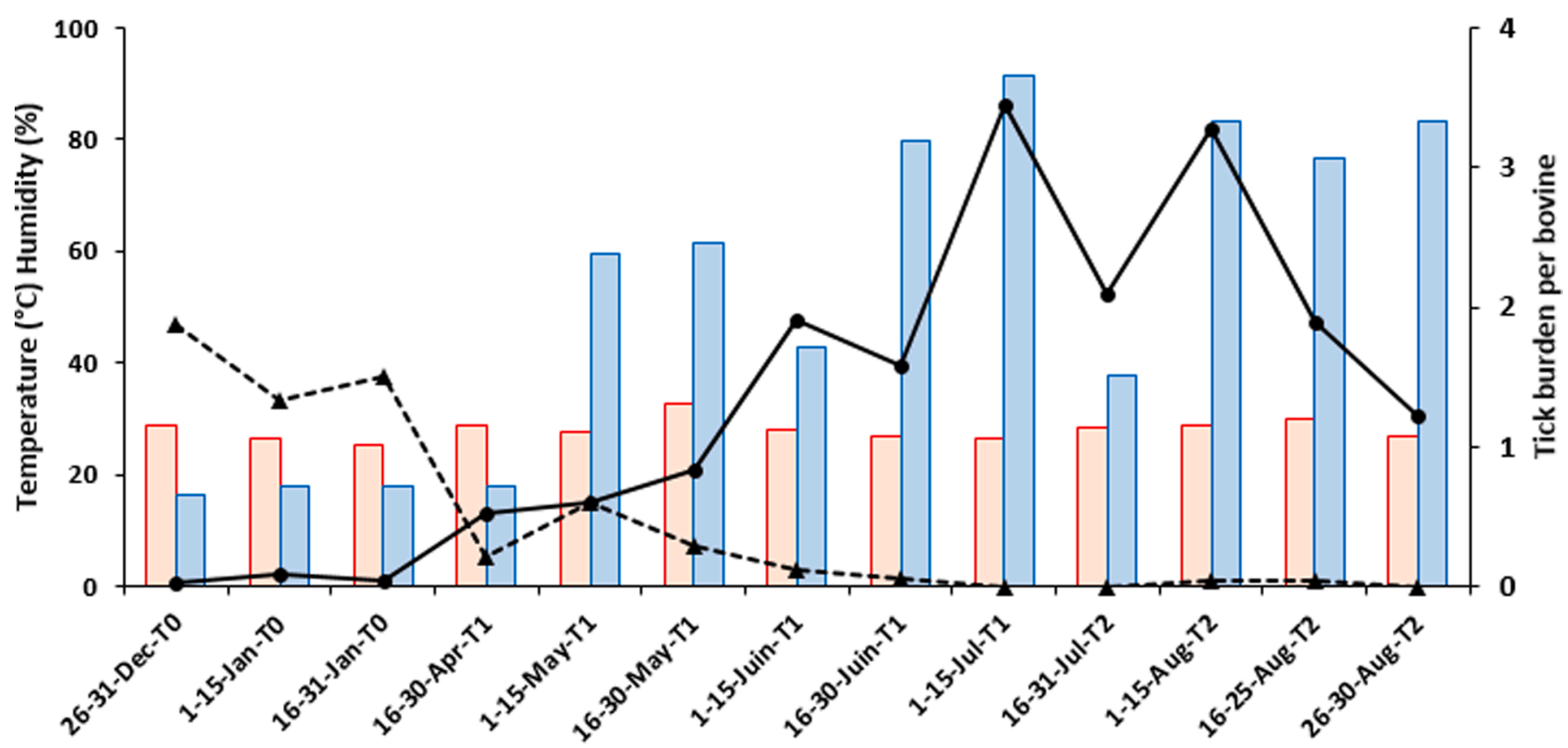

Fig. 4.. Variation of Amblyomma variegatum nymph and adult stages abundance during one seasonal migration. 
Table 5.

Tick-borne pathogens found in cattle.

\begin{tabular}{|c|c|c|c|c|c|c|c|c|c|c|c|c|}
\hline \multirow[b]{2}{*}{ Tick species } & \multicolumn{4}{|c|}{ T0 Burkina Faso } & \multicolumn{3}{|l|}{ T1 Benin } & \multicolumn{5}{|c|}{ T2 Burkina Faso } \\
\hline & $\begin{array}{l}\text { Gou } \\
(n=62)\end{array}$ & $\begin{array}{l}\text { Kom } \\
(n=75)\end{array}$ & $\begin{array}{l}\text { Tap } \\
(n=73)\end{array}$ & $\begin{array}{l}\mathrm{N}=210(\mathrm{P} \\
\%)\end{array}$ & $\begin{array}{l}\text { Ata } \\
(n=203)\end{array}$ & $\begin{array}{l}\text { Ali } \\
(n=7)\end{array}$ & $\begin{array}{l}\mathrm{N}=210(\mathrm{P} \\
\%)\end{array}$ & $\begin{array}{l}\text { Gou } \\
(n=62)\end{array}$ & $\begin{array}{l}\text { Kom } \\
(n=75)\end{array}$ & $\begin{array}{l}\text { Tap } \\
(n=73)\end{array}$ & $\begin{array}{l}\mathrm{N}=210(\mathrm{P} \\
\%)\end{array}$ & $\begin{array}{l}\mathrm{K}-\mathrm{W} \text { (p- } \\
\text { value) }\end{array}$ \\
\hline $\begin{array}{l}\text { Theileria } \\
\text { annulata }\end{array}$ & - & 2 & 1 & $3(1.4)$ & 22 & - & $22(10.5)$ & 1 & - & & $1(0.5)$ & $4.82(0.089)$ \\
\hline $\begin{array}{l}\text { Theileria } \\
\text { mutans }\end{array}$ & 29 & 66 & 71 & $166(79)$ & 155 & 4 & $\begin{array}{l}159 \\
(75.7)\end{array}$ & 60 & 18 & - & 78 (37) & $\begin{array}{l}17.97(< \\
0.0001)\end{array}$ \\
\hline $\begin{array}{l}\text { Theileria } \\
\text { velifera }\end{array}$ & 19 & 55 & 61 & $\begin{array}{l}135 \\
(64.3)\end{array}$ & 127 & 1 & $128(61)$ & 35 & 8 & - & $43(20.5)$ & $\begin{array}{l}24.50(< \\
0.0001)\end{array}$ \\
\hline Babesia bovis & - & 3 & 4 & $7(3.3)$ & - & - & 一 & - & - & - & 一 & - \\
\hline $\begin{array}{l}\text { Babesia } \\
\quad \text { bigemina }\end{array}$ & 2 & 4 & 4 & $10(4.8)$ & 19 & 1 & $20(9.5)$ & 3 & - & - & $3(1.4)$ & $\begin{array}{l}10.81 \\
(0.0045)\end{array}$ \\
\hline $\begin{array}{l}\text { Anaplasma } \\
\text { marginale }\end{array}$ & - & 4 & 2 & $6(2.9)$ & 23 & - & $23(11)$ & - & - & 2 & $2(1)$ & $\begin{array}{l}14.33 \\
(0.0008)\end{array}$ \\
\hline $\begin{array}{c}\text { Anaplasma } \\
\text { centrale }\end{array}$ & - & 1 & - & $1(0.5)$ & - & - & - & - & 2 & - & $2(0.9)$ & - \\
\hline
\end{tabular}

Gou: Gourma, Kom: Kompienga, Tap: Tapoa, Ata: Atacora, Ali : Alibori, K-W : Kruskal Walis test

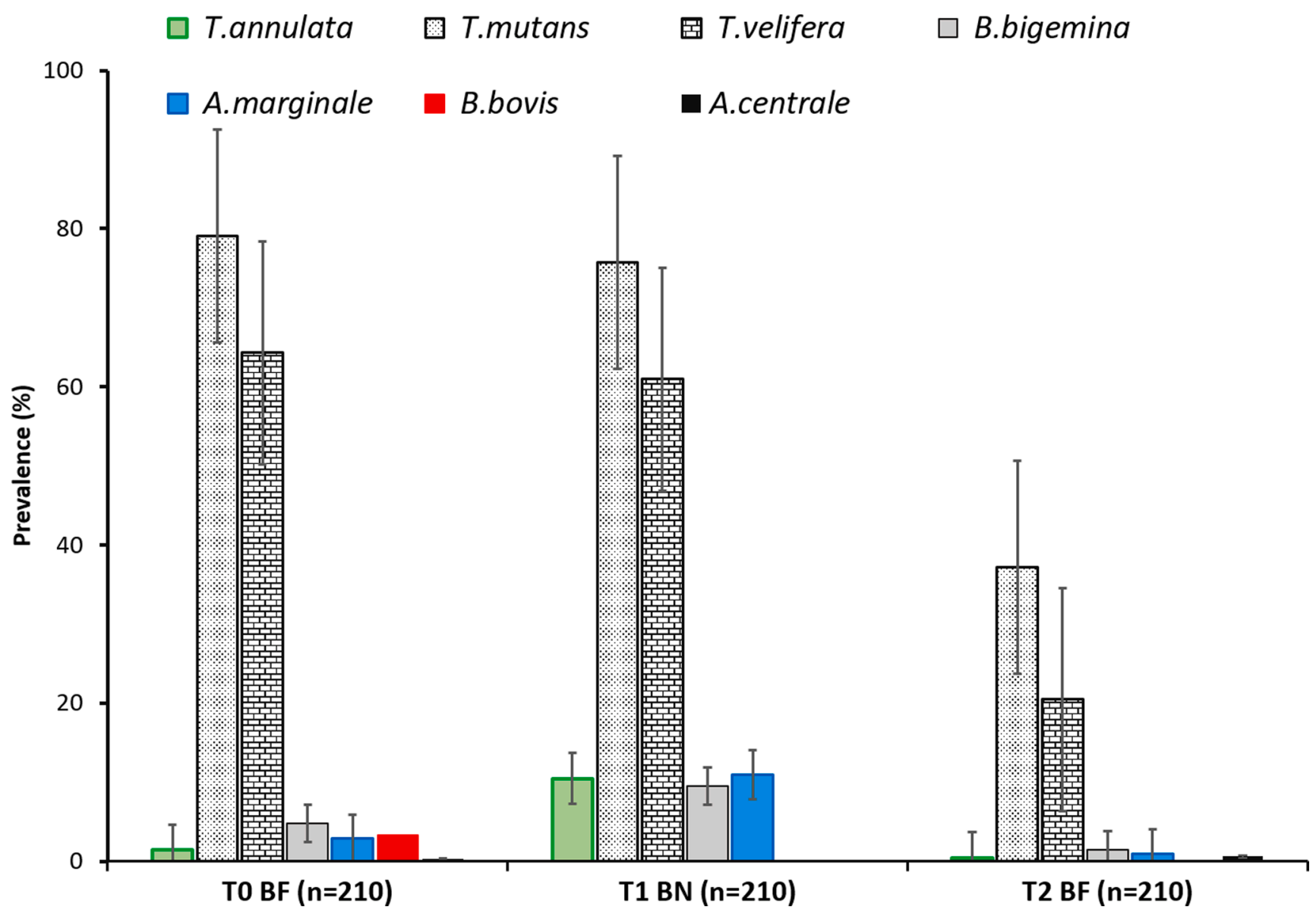

Fig. 5.. Overall prevalence of tick-borne pathogens found in cattle blood at T0BF, T1BN and T2BF. Legend: BF: Burkina Faso, BN: Benin.

A. variegatum, the most abundant and the most collected tick species in the study area (Stachurski, 2000; Adakal et al., 2010 ; Kouassi et al., 2016 ; Biguezoton et al., 2016). The nymphs A. variegatum were highly abundant at TOBF at the herds departure for transhumance as in A. variegatum triphasic life cycle, the nymph stage infests hosts (cattle) preferentially in dry season with peaks in January and February in tropical regions (Stachurski et al, 1993). After cattle moving in northern $\mathrm{BN}$ (T1BN), a decrease of nymph abundance and an increase of the adult abundance was observed. This result could reflect the fact that at T1BN, nymphs have finished their blood feeding on cattle. They therefore let themselves drop into the vegetation on the ground, to achieve moulting (transition from nymph to adult) for between 30-60 days (Pegram and Banda, 1990). Simultaneously, the nymphs that have finished moulting at TOBF ("new" adults), begin to climb on cattle at T1BN for their blood feeding and mating. The males attach first and produce attractive pheromones (AAP: aggregation-attachment pheromones) for the females who then attach. The blood meal varies from 6 to 7 days in males and up to 8 days in females (Barre and Garris, 1990; Stachurski, 2000). This will lead them to engorgement, required for eggs laying and then hatching. Such blood meal coincides with the warmer season of the year, which corresponds to T2BF in this survey, resulting in an increase in their abundance. This explains why $A$. variegatum adult's abundance is 
Table 6.

Prevalence of tick-borne pathogens detected in tick pools.

\begin{tabular}{|c|c|c|c|c|c|c|c|}
\hline Tick Species & $\begin{array}{l}\text { Tick Pools (1-5 } \\
\text { ticks) }\end{array}$ & $\begin{array}{l}\text { T. annulata No. } \\
(\%)\end{array}$ & $\begin{array}{l}\text { T. mutans No. } \\
(\%)\end{array}$ & $\begin{array}{l}\text { T. velifera No. } \\
(\%)\end{array}$ & $\begin{array}{l}\text { B. bovis No. } \\
(\%)\end{array}$ & $\begin{array}{l}\text { B. bigemina No. } \\
(\%)\end{array}$ & $\begin{array}{l}\text { E. ruminantium No. } \\
(\%)\end{array}$ \\
\hline \multicolumn{8}{|l|}{ T0 BURKINA FASO } \\
\hline Amblyomma variegatum & 176 & $3(1.7)$ & $12(6.8)$ & $5(2.8)$ & - & $1(0.6)$ & $1(0.6)$ \\
\hline Hyalomma rufipes & 58 & - & - & $1(1.7)$ & - & - & - \\
\hline Rhipicephalus geigyi & 59 & - & $4(6.8)$ & - & $1(1.7)$ & - & - \\
\hline \multirow{2}{*}{$\begin{array}{l}\text { Rhipicephalus } \\
\text { decoloratus }\end{array}$} & 54 & $2(3.7)$ & $1(1.9)$ & $2(3.7)$ & $1(1.9)$ & - & - \\
\hline & $\mathrm{N}=347$ & $5(1.4)$ & $17(4.9)$ & $8(2.3)$ & $2(0.6)$ & $1(0.3)$ & $1(0.3)$ \\
\hline \multicolumn{8}{|l|}{ T1 BENIN } \\
\hline Amblyomma variegatum & 177 & - & $2(1.1)$ & $1(0.6)$ & - & - & - \\
\hline Hyalomma rufipes & 93 & - & $2(2.2)$ & - & - & - & - \\
\hline Rhipicephalus geigyi & 48 & - & $1(2)$ & $1(2)$ & - & - & - \\
\hline $\begin{array}{r}\text { Rhipicephalus } \\
\text { decoloratus }\end{array}$ & 13 & - & $2(15.4)$ & - & - & - & - \\
\hline \multirow[t]{2}{*}{ Rhipicephalus annulatus } & 1 & - & - & - & - & - & - \\
\hline & $\mathrm{N}=332$ & & $7(2.1)$ & $2(0.6)$ & - & - & - \\
\hline \multicolumn{8}{|l|}{ T2 BURKINA FASO } \\
\hline Amblyomma variegatum & 212 & $1(0.5)$ & $21(9.9)$ & $6(2.8)$ & - & $1(0.5)$ & $2(0.9)$ \\
\hline Hyalomma rufipes & 65 & - & $7(10.8)$ & $7(10.8)$ & $1(1.5)$ & - & - \\
\hline Rhipicephalus geigyi & 22 & - & $1(4.5)$ & - & - & - & - \\
\hline $\begin{array}{l}\text { Rhipicephalus } \\
\text { decoloratus }\end{array}$ & 4 & - & - & - & - & - & - \\
\hline \multirow[t]{2}{*}{ Rhipicephalus microplus } & 1 & - & - & - & - & - & - \\
\hline & $\mathrm{N}=304$ & $1(0.3)$ & $29(9.5)$ & $13(4.3)$ & $1(0.3)$ & $1(0.3)$ & $2(0.7)$ \\
\hline
\end{tabular}

positively related to the relative humidity variations, while the nymph's abundance is negatively related. Another tick species whose abundance is positively and significantly related with the relative humidity variations is $H$. rufipes, but this only concerns its adult stage, as Hyalomma immature stages preferentially parasitize birds and small rodents (Bakirci et al., 2011 ; Tomassone et al., 2004). Knowing Hyalomma species could be di- or triphasic, their low infestation in cattle at TOBF could be related to the fact that nymphs were completing their metamorphosis in the environment, and "new" adults had not yet started infesting the hosts. At the beginning of the rainy season at T1BN, they achieve moulting and begin to infest cattle and become more present at T2BF. Meanwhile, a negative relation was observed in $R$. decoloratus abundance with relative humidity. This is in line with some previous findings (Katiyatiya et al., 2014; Yawa et al., 2018) who reported that the favorable period for $R$. decoloratus proliferation is in summer, close to the beginning of rainy season in tropical regions (T1BN). Consequently, the increase of the relative humidity in rainy season (T2BF), leads to a decrease of its population as shown in Table 2 . The abundance of the species $R$. geigyi did not show any significant correlation with relative humidity variations. This is similar to the finding of Farougou (2009), who highlighted only a moderate correlation of this species to rainfall. As others Boophilus species, it presents several generations per year in tropical regions and occur at different periods. The temperature did not vary significantly during the study period; it did not show any particular influence on the level of infestation of tick species in cattle. Tick species such as $H$. impressum, $H$. nitidum, $R$. lunulatus and $R$. annulatus appeared only at T1BN and/or T2BF due to the beginning of the rainy season in March-April (T1BN) which triggered the end of the diapause period and their return to activity (host search, eggs hatching) as previously reported by Farougou et al. (2007).

Sampled herds were not invaded by $R$. microplus ticks at the return of cattle from transhumance at T2BF in eastern BF. Considering the 210 cattle surveyed, only one male specimen of $R$. microplus was identified on a male cattle less than 12 months old. It belonged to a herd having stayed in northern BN in Atacora department, in Materi commune. Moreover, at T2BF, three specimens (one male and two females) of the invasive tick specie were also sampled on another cattle, not included in the group of the 210 animals followed. This animal belongs to another herd which has also stayed in the same commune in Benin. According to the distribution of risk scores for the occurrence and establishment of R. microplus in the study area (Zannou et al., 2020), this commune appears to be one of the localities showing the highest risk scores (69-80\%). As some transhumant herds stayed in the same commune, this could lead to suggest an infestation of more transhumant cattle by $R$. microplus, but which were not detected. Some cattle involved in the survey were only infested at T1BN and/or T2BF by $H$. impressum, $H$. nitidum, $R$. lunulatus, $R$. annulatus (Table 2). These results evidenced that transhumance can favour new tick species acquirement by concerned animals. However, regarding the species recorded at the three periods of sampling, their relative abundance did not significantly vary. This suggests that transhumance can influence animal infestation by new tick species, without necessarily impacting tick abundance on transhumant animals. However, new tick species infestations during transhumance may lead to an increase of animals infestation level in a given region (Adakal et al., 2013; Biguezoton et al., 2016; Muhanguzi et al., 2020). Changes induced in tick populations by transhumance necessarily influence the prevalences of circulating TBP. At TOBF and T1BN, the TBP such as T. mutans and T. velifera prevalences recorded are in line with previous values reported in the study area (Ouedraogo et al., 2021) and in other African countries (Simuunza et al., 2011; Lorusso et al., 2016 ; Abanda et al., 2019). These two pathogens were the most prevalent at the three points of transhumance, showing overall prevalences significantly lower at T2BF, without a decrease of their vector tick population, A. variegatum (Bishop et al., 2004). Indeed, data obtained from the epidemiological survey revealed a large use of trypanocidal compounds among farmers involved in the survey $(26 / 28,92.9 \%$ of farmers) in rainy season, to prevent trypanosomosis. These include compounds such as diminazene aceturate, which is known to have an inhibitory effect on Theileria and Babesia species (Baek et al., 2002). This could lead to the detection of low prevalences of Theileria and Babesia species at T2BF. Moreover, the low prevalences of $B$. bigemina at T2BF and of $A$. marginale at T0BF and T2BF could be attributed to the low infestation of cattle by $R$. decoloratus (Walker, 2003), one of their vector ticks. The occurrence of this species is known to be favoured by low rainfall (Sungirai et al., 2018) such as the beginning of rainy season at T1BN.

Tick-borne pathogens identifications in cattle blood were confirmed by their presence in tick DNA samples. Except E. ruminantium and A. centrale, all TBP detected in cattle were also found in ticks, but with lower prevalences (Table 6). However, some TBP species were found in certain tick not known to be their vector (e.g. B. bigemina in A. variegatum). As this survey is not focusing on the competency assessment but on the circulating pathogens in tick and cattle during 

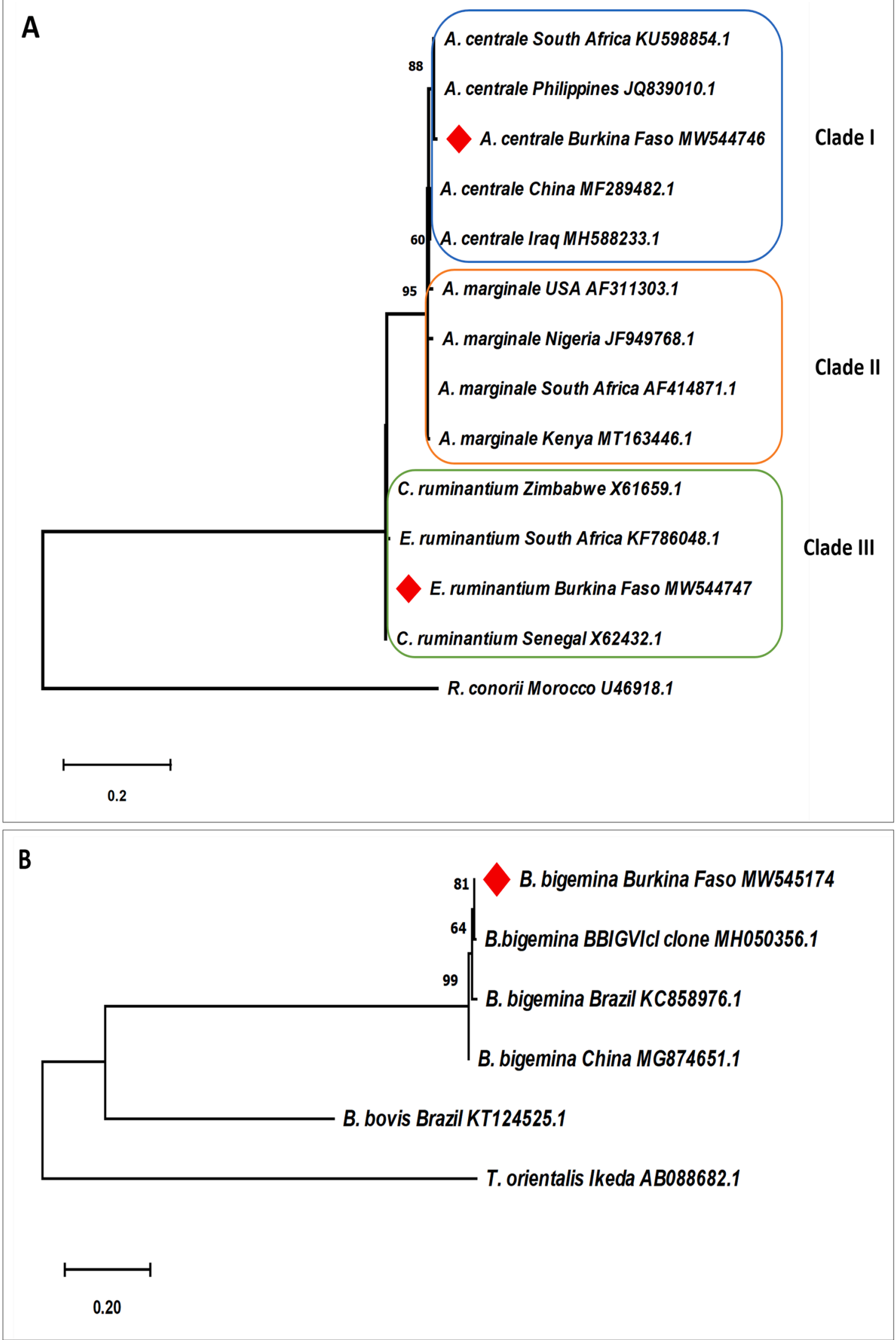

Fig. 6.. Phylogenetic trees of 16S rRNA gene sequences of Ehrlichia/Anaplasma (A) and 18S rRNA gene sequences of Babesia bigemina (B) constructed with the Maximum Likelihood method. Evolutionary history was inferred applying Tamura-Nei model. Red squares refer to sequences generated in the present study. 
transhumance, we did not investigate if these tick species are competent for the concerned pathogen transmission. Nevertheless, it is noteworthy that blood was scraped from engorged ticks prior to DNA extraction, but it is not excluded that they could be positive because of a blood meal taken from infected animals. Elsewhere, this survey evidenced some TBP species, rarely reported in the study area. This include $T$. annulata, whose presence was reported for the first time in 2021 (Ouedraogo et al., 2021) . This concern also A. centrale, detected in cattle at TOBF and $\mathrm{T} 2 \mathrm{BF}$, with prevalence in line with that reported in Nigeria (Lorusso et al., 2016). To the best of our knowledge, this represents the first report of this TBP species in BF. Even if it is known to cause only milder form of cattle anaplasmosis (Rajput et al., 2005), its detection in the present study is of significant importance as this provides new findings on BF tick-borne pathogens knowledge.

The main limitation of this survey was that a new tick collection has not been possible in eastern BF after the return of the transhumant herds. The detection of a few specimens of $R$. microplus is not sufficient to confirm the establishment of the species in the study area. A new collection supplemented by molecular characterisation of $R$. microplus and a study on its spatial dissemination is further required.

\section{Conclusions}

The impact of transhumance on the spread of ticks and their associated pathogens is closely linked to the influence of seasonal variations, as the transhumance duration is extended over rainy and dry seasons in tropical regions. Pastoralists in eastern BF leave their farms in the dry season because of late onset of rains, but expose their cattle to new tick species (e.g. $H$. impressum, $H$. nitidum, $R$. lunulatus, $R$. annulatus, $R$. microplus) infestations in northern BN, where the rainfall settles earlier. Some of these tick species (e.g. R. lunulatus, R. microplus) remain on cattle until they return in eastern BF, while others disappear or their abundance decreases (e.g. R. geigyi, R. decoloratus) due to the completion of their natural life cycle. These different variations necessarily influence the TBP prevalences during the seasonal transhumance. Overall, TBP prevalences were high at TOBF and T1BN, and low at T2BF, not only because of the fluctuations in their vector tick populations, but also because of the use of diminazene aceturate having proved inhibitory effect on Theileria and Babesia species (Baek et al., 2002). Elsewhere, this survey highlights for the first time the presence of $A$. centrale in $\mathrm{BF}$, providing new data on its dissemination pattern in western Africa.

\section{Ethics approval and consent to participate}

The study was approved by CIRDES ethics committee (CE-CIRDES) for animal experimentation according to the reference number 001-02/ 2017/CE-CIRDES and was based on verbal consent of farmers

\section{Availability of data and materials}

The datasets used during the current study are available from the corresponding author on reasonable request

\section{Funding}

This work was supported by the Academy of Research and Higher Education (ARES-CCD) [RPD Transticks].

\section{Sample Credit author statement}

Laetitia LEMPEREUR (LL), Abel BIGUEZOTON (AB), Patrick Yao KOUASSI (PYK), Claude SAEGERMAN (CS): Conceptualization, Methodology, Project administration Achille Sougrinoma OUEDRAOGO (ASO), Olivier Mahuton ZANNOU (OMZ): Data acquisition \& Field work; LL, AB: Supervision ASO: Writing - original draft; LL, CS, AB, Marinda OOSTHUIZEN, Souaïbou FAROUGOU, Adrien Marie Gaston
BELEM, PYK: Review \& editing

\section{Author statement}

The content of this paper has not been published and is not under consideration for publication elsewhere. No competing interesting, All authors approve its publication

\section{Declaration of Competing Interests}

The authors declare that they have no competing interests.

\section{Acknowledgment}

The authors are grateful to Adrien Zoungrana and Sebastien Zoungrana from CIRDES (Bobo-Dioulasso), Milana Troskie from the University of Pretoria (South Africa) for their technical support. They thank farmers of eastern BF for their consent to participate in this study. They are also grateful to agents of the veterinary services and local authorities of eastern BF and northern BN for their collaboration. Positive controls were provided by the Department of veterinary Tropical Diseases, Faculty Veterinary Science, University of Pretoria and the Institute of Tropical Medicine of Antwerp (South Africa).

\section{References}

Abanda, B., Paguem, A., Abdoulmoumini, M., Kingsley, M.T., Renz, A., Eisenbarth, A., 2019. Molecular identification and prevalence of tick-borne pathogens in zebu and taurine cattle in North Cameroon. Parasit. Vectors 12, 448. https://doi.org/ 10.1186/s13071-019-3699-x.

Abdourazakou, A., 2016. La transhumance transfrontalière: source de dégradation du couvert végétal et de conflits dans la région des savanes (Nord-Togo), 2. Rev. Géographie Univ.

Adakal, Biguezoton, A., Zoungrana, S., Courtin, F., De Clercq, E.M., Madder, M., 2013. Alarming spread of the Asian cattle tick Rhipicephalus microplus in West Africa — another three countries are affected: Burkina Faso, Mali and Togo. Exp. Appl. Acarol. 61, 383-386. https://doi.org/10.1007/s10493-013-9706-6.

Adakal, H., Gavotte, L., Stachurski, F., Konkobo, M., Henri, H., Zoungrana, S., Huber, K., Vachiery, N., Martinez, D., Morand, S., Frutos, R., 2010. Clonal origin of emerging populations of Ehrlichia ruminantium in Burkina Faso. Infect. Genet. Evol. 10, 903-912. https://doi.org/10.1016/j.meegid.2010.05.011.

Adehan, S.B., Abel Biguezoton, A., Adakal, H., Assogba, M.N., Zoungrana, S., Gbaguidi, A.M., 2016. Acaricide resistance of Rhipicephalus microplus ticks in Benin. Afr J Agric Res 11 (14), 1199-1208. https://doi.org/10.5897/ AJAR2015.10619, 2016.

Baek, B.-K., Lee, Y.-J., Kim, B.-S., 2002. Antiparasitic Effect of Diminazene Aceturate on Theileria sergenti Types in Calves. Korean J. Vet. Res. 42, 261-268.

Bakirci, S., Sarali, H., Aydin, L., Latif, A., Eren, H., Karagenç, T., 2011. Hyalomma rufipes (Koch, 1844) infesting cattle in the West Aegean region of Turkey. Turk. J. Vet. Anim. Sci. 35, 359-363.

Barre, N., Garris, G.I., 1990. Biology and ecology of Amblyomma variegatum (Acari: Ixodidae) in the Caribbean: implications for a regional eradication program. J. Agric. Entomol. 7, 1-9.

Bekker, C.P.J., de Vos, S., Taoufik, A., Sparagano, O.A.E., Jongejan, F., 2002a. Simultaneous detection of Anaplasma and Ehrlichia species in ruminants and detection of Ehrlichia ruminantium in Amblyomma variegatum ticks by reverse line blot hybridization. Vet. Microbiol. 89, 223-238. https://doi.org/10.1016/S03781135(02)00179-7.

Biguezoton, A., Adehan, S., Adakal, H., Zoungrana, S., Farougou, S., Chevillon, C., 2016. Community structure, seasonal variations and interactions between native and invasive cattle tick species in Benin and Burkina Faso. Parasites Vectors 9. https:// doi.org/10.1186/s13071-016-1305-z.

Bishop, R., Musoke, A., Morzaria, S., Gardner, M., Nene, V., 2004. Theileria: intracellular protozoan parasites of wild and domestic ruminants transmitted by ixodid ticks. Parasitology 129, S271-S283. https://doi.org/10.1017/S0031182003004748.

Bouslikhane, M., 2015. Cross Border Movements of Animals and Animal Products and their Relevance to the Epidemiology of Animal Diseases in Africa. L'Organisation Mondiale de la Santé Animale (OIE), Paris, France.

Brottem, L., Turner, M.D., Butt, B., Singh, A., 2014. Biophysical variability and pastoral rights to resources: West African Transhumance Revisited. Hum Ecol 42, 351-365. https://doi.org/10.1007/s10745-014-9640-1.

Djenontin, J.A., Madjidou, O., Houinato, M.R., Mensah, G.A., Sinsin, B.A., 2012. Le calendrier pastoral en élevage extensif dans le Nord-Est du Bénin : un outil de gestion du cheptel bovin de l'exploitation. Science et changements planétaires /Sécheresse 23, 261-270. https://doi.org/10.1684/sec.2012.0350.

Farougou, S., Tassou, A.W., Tchabode, D.M., Kpodekon, M., Boko, C., Youssao, A.K.I. 2007. Tiques et hémoparasites du bétail dans le nord-Bénin. Rev. Méd. Vét. 158, 463-467. 
Georges, K., Loria, G.R., Riili, S., Greco, A., Caracappa, S., Jongejan, F., Sparagano, O., 2001. Detection of haemoparasites in cattle by reverse line blot hybridisation with a note on the distribution of ticks in Sicily. Vet. Parasitol. 99, 273-286. https://doi. org/10.1016/S0304-4017(01)00488-5.

Gubbels, J.M., Vos, A.P.deD., Weide, M.van V.derD., Viseras, J., Schouls, L.M., Vries, E. deD., Jongejan, F., 1999. Simultaneous Detection of Bovine Theileria and Babesia Species by Reverse Line Blot Hybridization. J. Clin. Microbiol. 37, 1782-1789.

Gubbels, M.-J., Katzer, F., Hide, G., Jongejan, F., Shiels, B.R., 2000. Generation of a mosaic pattern of diversity in the major merozoite-piroplasm surface antigen of Theileria annulata. Mol. Biochem. Parasitol. 110, 23-32. https://doi.org/10.1016/ S0166-6851(00)00253-X.

He, L., Feng, H.-H., Zhang, W.-J., Zhang, Q.-L., Fang, R., Wang, L.-X., Tu, P., Zhou, Y.-Q., Zhao, J.-L., Oosthuizen, M.C., 2012. Occurrence of Theileria and Babesia species in water buffalo (Bubalus babalis, Linnaeus, 1758) in the Hubei province, South China. Vet. Parasitol. 186, 490-496. https://doi.org/10.1016/j.vetpar.2011.11.021.

Kabi, F., Magona, J.wW., Nasinyama, G.wW., Walubengo, J., 2008. Sero-prevalences of Tick-borne infections among the Nkedi Zebu and Ankole cattle in Soroti district, Uganda. J. Protozool. Res. 18, 61-70. https://doi.org/10.32268/jprotozoolres.18.2 61.

Katiyatiya, C.L.F., Muchenje, V., Mushunje, A., 2014. Farmers' Perceptions and Knowledge of Cattle Adaptation to Heat Stress and Tick Resistance in the Eastern Cape, South Africa. Asian-Australas. J. Anim. Sci. 27, 1663-1670. https://doi.org/ 10.5713/ajas.2014.14174.

Kouassi, P., Y., Zoungrana, S., Hema, M., D., Diallo, M., K., Biguezoton, A., Traore, A., Toure, A., 2016. Distribution Des Tiques Du Bétail dans cinq régions du Burkina Faso et évaluation de la connaissance de ces ectoparasites par les éleveurs : Nécessité de campagnes de sensibilisation. Science et Technique.

Lesse, P., Houinato, M.R.B., Djenontin, J., Dossa, H., Yabi, B., Toko, I., Tente, B., Sinsin, B., 2015. Transhumance en République du Bénin : états des lieux et contraintes. Int. J. Biol. Chem. Sci. 9, 2668-2681. https://doi.org/10.4314/ijbcs. v9i5.37.

Lorusso, V., Wijnveld, M., Majekodunmi, A.O., Dongkum, C., Fajinmi, A., Dogo, A.G., Thrusfield, M., Mugenyi, A., Vaumourin, E., Igweh, A.C., Jongejan, F., Welburn, S.C., Picozzi, K., 2016. Tick-borne pathogens of zoonotic and veterinary importance in Nigerian cattle. Parasit. Vectors 9, 217. https://doi.org/10.1186/s13071-016-15047.

Muhanguzi, D., Byaruhanga, J., Amanyire, W., Ndekezi, C., Ochwo, S., Nkamwesiga, J., Mwiine, F.N., Tweyongyere, R., Fourie, J., Madder, M., Schetters, T., Horak, I., Juleff, N., Jongejan, F., 2020. Invasive cattle ticks in East Africa: morphological and molecular confirmation of the presence of Rhipicephalus microplus in south-eastern Uganda. Parasit. Vectors 13, 165. https://doi.org/10.1186/s13071-020-04043-z.

Nijhof, A.M., Penzhorn, B.L., Lynen, G., Mollel, J.O., Morkel, P., Bekker, C.P.J., Jongejan, F., 2003. Babesia bicornis sp. nov. and Theileria bicornis sp. nov.: tickBorne Parasites Associated with Mortality in the Black Rhinoceros (Diceros bicornis). J. Clin. Microbiol. 41, 2249-2254. https://doi.org/10.1128/JCM.41.5.22492254.2003.

Nijhof, A.M., Pillay, V., Steyl, J., Prozesky, L., Stoltsz, W.H., Lawrence, J.A., Penzhorn, B. L., Jongejan, F., 2005. Molecular characterization of Theileria species associated with mortality in four species of African Antelopes. J. Clin. Microbiol. 43, 5907-5911. https://doi.org/10.1128/JCM.43.12.5907-5911.2005.

Ouedraogo, A.S., Zannou, O.M., Biguezoton, A.S., Yao, K.P., Belem, A., Farougou, S., Oosthuizen, M., Saegerman, C., Lempereur, L., 2021. Cattle ticks and associated tickborne pathogens in Burkina Faso and Benin: apparent northern spread of Rhipicephalus microplus in Benin and first evidence of Theileria velifera and Theileria annulata. Ticks Tick-Borne Dis., 101733 https://doi.org/10.1016/j. ttbdis.2021.101733.
Pegram, R.G., Banda, D.S., 1990. Ecology and phenology of cattle ticks in Zambia: development and survival of free-living stages. Exp. Appl. Acarol. 8, 291-301. https://doi.org/10.1007/BF01202139.

Rajput, Z.I., Hu, S., Arijo, A.G., Habib, M., Khalid, M., 2005. Comparative study of Anaplasma parasites in tick carrying buffaloes and cattle. J. Zhejiang Univ. Sci. B 6, 1057-1062. https://doi.org/10.1631/jzus.2005.B1057.

Schouls, L.M., Pol, I.V.D., Rijpkema, S.G.T., Schot, C.S., 1999. Detection and Identification of Ehrlichia, Borrelia burgdorferi Sensu Lato, and Bartonella Species in Dutch Ixodes ricinus Ticks. J. Clin. Microbiol. 37, 2215-2222. https://doi.org/ 10.1128/JCM.37.7.2215-2222.1999.

Simuunza, M., Weir, W., Courcier, E., Tait, A., Shiels, B., 2011. Epidemiological analysis of tick-borne diseases in Zambia. Vet. Parasitol. 175, 331-342. https://doi.org/ 10.1016/j.vetpar.2010.09.027.

Stachurski, F., 2000. Invasion of West African cattle by the tick Amblyomma variegatum. Med. Vet. Entomol. 14, 391-399. https://doi.org/10.1046/j.13652915.2000.00246.x.

Stachurski, F., Musonge, E.N., Achu-kwi, M.D., Saliki, J.T., 1993. Impact of natural infestation of Amblyomma variegatum on the liveweight gain of male Gudali cattle in Adamawa (Cameroon). Vet. Parasitol. 49, 299-311. https://doi.org/10.1016/ 0304-4017(93)90128-A.

Sungirai, M., Moyo, D.Z., De Clercq, P., Madder, M., Vanwambeke, S.O., De Clercq, E.M., 2018. Modelling the distribution of Rhipicephalus microplus and R. decoloratus in Zimbabwe. Vet. Parasitol. Reg. Stud. Rep. 14, 41-49. https://doi.org/10.1016/j. vprsr.2018.08.006.

Tomassone, L., Camicas, J.-L., Pagani, P., Diallo, O.T., Mannelli, A., Meneghi, D.D., 2004. Monthly dynamics of ticks (Acari: Ixodida) infesting N'Dama cattle in the Republic of Guinea. Exp. Appl. Acarol. 32, 209-218. https://doi.org/10.1023/B: APPA.0000021771.34520.ab.

Tønnesen, M.H., Penzhorn, B.L., Bryson, N.R., Stoltsz, W.H., Masibigiri, T., 2004. Displacement of Boophilus decoloratus by Boophilus microplus in the Soutpansberg region, Limpopo Province, South Africa. Exp. Appl. Acarol. 32, 199-208. https://doi. org/10.1023/B:APPA.0000021789.44411.b5.

Walker, R.A., Bouttaour, A., Camicas, J.L., 2003. Ticks of domestic animals in Africa. A guide to identifi cation of species. In: Bioscience Reports, 2003. Edinburgh,UK, p. 114.

Yakhchali, M., Hosseine, A., 2006. Prevalence and ectoparasites fauna of sheep and goats flocks in Urmia suburb. Iran. Vet. Arh. 76, 431-442.

Yawa, M., Nyangiwe, N., Muchenje, V., Kadzere, C.T., Mpendulo, T.C., Marufu, M.C., 2018. Ecological preferences and seasonal dynamics of ticks (Acari: Ixodidae) on and off bovine hosts in the Eastern Cape Province, South Africa. Exp. Appl. Acarol. 74, 317-328. https://doi.org/10.1007/s10493-018-0234-2.

Yeruham, I., Hadani, A., Galker, F., Rosen, S., 1996. The seasonal occurrence of ticks (Acari: Ixodidae) on sheep and in the field in the Judean area of Israel. Exp. Appl. Acarol. 20, 47-56. https://doi.org/10.1007/BF00051476.

Yisaschar-Mekuzas, Y., Jaffe, C.L., Pastor, J., Cardoso, L., Baneth, G., 2013. Identification of Babesia species infecting dogs using reverse line blot hybridization for six canine piroplasms, and evaluation of co-infection by other vector-borne pathogens. Vet. Parasitol. 191, 367-373. https://doi.org/10.1016/j.vetpar.2012.09.002.

Zannou, O.M., Ouedraogo, A.S., Biguezoton, A.S., Lempereur, L., Patrick Yao, K., Abatih, E., Zoungrana, S., Lenaert, M., Toe, P., Farougou, S., Saegerman, C., 2020. First digital characterization of the transhumance corridors through Benin used by cattle herds from Burkina Faso and associated risk scoring regarding the invasion of Rhipicephalus (Boophilus) microplus. Transbound. Emerg. Dis. https://doi.org/ 10.1111/tbed.13855. 